\title{
Elevation of Circulating LIGHT (TNFSF14) and Interleukin-18 Levels in Sepsis-Induced Multi-Organ Injuries
}

Hui-Qi Qu ${ }^{1}$, Jingchun $\mathrm{Qu}^{1}$, Thomas Dunn ${ }^{2}$, James Snyder ${ }^{1}$, Todd A. Miano ${ }^{3}$, John Connolly ${ }^{1}$, Joseph Glessner ${ }^{1,4,5}$, Brian J. Anderson², John P. Reilly ${ }^{2}$, Tiffanie K. Jones ${ }^{2,3}$, Heather M. Giannini $^{2}$, Roseline S. Agyekum ${ }^{2}$, Ariel R. Weisman ${ }^{2}$, Caroline A.G. Ittner ${ }^{2}$, Laura G. Rodrigues ${ }^{2}$, Charlly Kao ${ }^{1}$, Michael G.S. Shashaty ${ }^{3}$, Patrick Sleiman ${ }^{1,4,5}$, Nuala J. Meyer, ${ }^{2,6}$, Hakon Hakonarson $^{1,4,5,7 \dagger}$.

Affiliations:

${ }^{1}$ The Center for Applied Genomics, Children's Hospital of Philadelphia, Philadelphia, Pennsylvania, 19104, USA.

${ }^{2}$ Pulmonary, Allergy, and Critical Care Medicine Division, University of Pennsylvania Perelman School of Medicine, 3600 Spruce Street 5039 Gates Building, Philadelphia, PA, 19104, USA.

${ }^{3}$ Center for Clinical Epidemiology and Biostatistics, Perelman School of Medicine at the University of Pennsylvania, Philadelphia, PA, 19104, USA;

${ }^{4}$ Department of Pediatrics, The Perelman School of Medicine, University of Pennsylvania, Philadelphia, Pennsylvania, 19104, USA.

${ }^{5}$ Division of Human Genetics, Children's Hospital of Philadelphia, Philadelphia, Pennsylvania, 19104, USA.

${ }^{6}$ Center for Translational Lung Biology and Lung Biology Institute, Perelman School of Medicine, Philadelphia PA 19104, USA

${ }^{7}$ Division of Pulmonary Medicine, Children's Hospital of Philadelphia, Philadelphia, Pennsylvania, 19104, USA.

$\dagger$ Corresponding author and reprint requests should be addressed to:

Dr. Hakon Hakonarson

Center for Applied Genomics

3615 Civic Center Blvd

Abramson Building

Philadelphia, PA 19104, United States of America

Telephone: 267-426-0088

Fax: 267-426-0363 
medRxiv preprint doi: https://doi.org/10.1101/2021.05.25.21257799; this version posted May 27, 2021. The copyright holder for this preprint (which was not certified by peer review) is the author/funder, who has granted medRxiv a license to display the preprint in perpetuity.

All rights reserved. No reuse allowed without permission.

Email: hakonarson@chop.edu

Word count: 3870

Number of tables and figures: 5 tables and 1 figure 
medRxiv preprint doi: https://doi.org/10.1101/2021.05.25.21257799; this version posted May 27, 2021. The copyright holder for this preprint (which was not certified by peer review) is the author/funder, who has granted medRxiv a license to display the preprint in perpetuity.

All rights reserved. No reuse allowed without permission.

\begin{abstract}
Objective The cytokines, LIGHT (TNFSF14) and Interleukin-18 (IL-18), are two important therapeutic targets due to their central roles in the function of activated T cells and inflammatory injury. LIGHT was recently shown to play a major role in COVID19 induced acute respiratory distress syndrome (ARDS), reducing mortality and hospital stay. This study aims to investigate the associations of LIGHT and IL-18 with non-COVID19 related ARDS, acute hypoxic respiratory failure (AHRF) or acute kidney injury (AKI), secondary to viral or bacterial sepsis.
\end{abstract}

Research Design and Methods A cohort of 280 subjects diagnosed with sepsis, including 91 cases with sepsis triggered by viral infections, were investigated in this study and compared to healthy controls. Serum LIGHT, IL-18, and 59 other biomarkers (cytokines, chemokines and acute-phase reactants) were measured and associated with symptom severity.

Results ARDS was observed in $36 \%$ of the patients, with $29 \%$ of the total patient cohort developing multi-organ failure (failure of two or more organs). We observed significantly increased LIGHT level (>2SD above mean of healthy subjects) in both bacterial sepsis patients $(\mathrm{P}=1.80 \mathrm{E}-05)$ and patients with sepsis from viral infections $(\mathrm{P}=1.78 \mathrm{E}-03)$. In bacterial sepsis, increased LIGHT level associated with ARDS, AKI and higher Apache III scores, findings also supported by correlations of LIGHT with other biomarkers of organ failures, suggesting LIGHT may be an inflammatory driver. IL-18 levels were highly variable across individuals, and consistently correlated with Apache III scores, mortality, and AKI, in both bacterial and viral sepsis.

Conclusions For the first time, we demonstrate independent effects of LIGHT and IL-18 in septic organ failures. LIGHT levels are significantly elevated in non-COVID19 sepsis patients with ARDS and/or multi-organ failures suggesting that anti-LIGHT therapy may be effective therapy in a subset of patients with sepsis. Given the large variance of plasma IL-18 among septic subjects, targeting this pathway raises opportunities that require a precision application.

Key words: acute hypoxic respiratory failure; acute kidney injury; acute respiratory distress syndrome; Interleukin-18; LIGHT; sepsis; viral infections 
medRxiv preprint doi: https://doi.org/10.1101/2021.05.25.21257799; this version posted May 27, 2021. The copyright holder for this preprint (which was not certified by peer review) is the author/funder, who has granted medRxiv a license to display the preprint in perpetuity.

All rights reserved. No reuse allowed without permission.

\section{Introduction}

The cytokine LIGHT (CD258), also known as tumor necrosis factor superfamily member 14 (TNFSF14), is a secreted protein of the TNF superfamily, recognized by the herpesvirus entry mediator (HVEM), the lymphotoxin B receptor (LTBR), and by decoy receptor, DcR ${ }^{1}$. LIGHT exhibits inducible expression and competes with herpes virus glycoprotein D for binding to HVEM on T lymphocytes ${ }^{2}$. LIGHT is a ligand for TNFRSF14, which is a member of the tumor necrosis factor receptor superfamily, also known as HVEM ligand (HVEML). This protein functions as a costimulatory factor for the activation of lymphoid cells aimed at opposing infection by herpesvirus ${ }^{2}$. It additionally stimulates the proliferation of $\mathrm{T}$ cells, and triggers apoptosis of various tumor cells ${ }^{3}$. In addition to LIGHT, Interleukin-18 (IL-18) as the interferon$\gamma$ inducing factor and a central inflammatory mediator, has also been demonstrated to play a role in septic shock, organ failures, and sepsis mortality, suggesting a potential therapeutic target in sepsis $^{4-6}$.

Inflammatory reactions and immune responses are known to be dysregulated and compromised in patients with sepsis, the syndrome of infection complicated by organ injuries ${ }^{7,8}$. In this regard, acute respiratory distress syndrome (ARDS) and acute kidney injury (AKI) are major complications of severe infections ${ }^{9,10}$, while the mechanisms of immune dysfunction causing these complications remains unknown. Sepsis typically manifests as an uncontrolled systemic inflammatory process, involving the microvasculature of multiple organ systems and manifesting as organ injury in one or multiple organs, including ARDS, AKI, disseminated intravascular coagulation (DIC) $)^{11}$, or delirium ${ }^{12,13}$. Liver, heart, and brain failures are also relatively common manifestations.

LIGHT, has recently come into the spotlight as a potent pro-inflammatory mediator and has been suggested as an important therapeutic target for immune regulation due to its central role in the function of activated T cells ${ }^{14-16}$. Previous study showed that soluble LIGHT induces proinflammatory changes in endothelial cells under systemic inflammatory activation ${ }^{17}$. The potential contribution of LIGHT to both inflammation and tissue fibrosis identifies it as a compelling causal contributor to ARDS and particularly fibroproliferative ARDS, which has very poor clinical outcomes. Given the high proportion of patients with COVID-19 and ARDS who seem to develop rapid fibrosis ${ }^{18}$, LIGHT may be involved in COVID-19-related ARDS. Indeed, several studies have demonstrated elevated LIGHT levels in serum of COVID ARDS patients ${ }^{19-21}$. A follow up clinical trial using LIGHT neutralizing mAb was successful in reducing lung injury, ventilator time in ICU, hospital stay and mortality ${ }^{22}$. A recent study also suggested an important role of LIGHT/HVEM expression in experimental lung injury in mice ${ }^{23}$.

Among other inflammatory biomarkers measured in this study, IL-18 is another proinflammatory LIGHT-like cytokine known to activate and regulate both innate and adaptive immunity. Its dysregulation has been shown to result in auto-inflammatory diseases ${ }^{24,25}$. While IL-18 neutralizing mAb has been suggested for the treatment of various autoimmune and autoinflammatory diseases by experimental studies and clinical trails ${ }^{26,27}$, its role in sepsis is less clear.

We sought to investigate the potential role of LIGHT and IL18 in bacterial and viral-induced sepsis unrelated to COVID-19, and specifically the proteins' associations with ARDS, acute 
medRxiv preprint doi: https://doi.org/10.1101/2021.05.25.21257799; this version posted May 27, 2021. The copyright holder for this preprint (which was not certified by peer review) is the author/funder, who has granted medRxiv a license to display the preprint in perpetuity.

All rights reserved. No reuse allowed without permission.

hypoxic respiratory failure, and AKI as major sepsis complications in 280 patients with sepsis. Of those, 189 had either culture proven or presumed bacterial sepsis and 91 had PCR-diagnosed viral sepsis that resulted in hospitalization and admission to the intensive care unit (ICU). To contextualize the inflammatory cytokine milieu given the relative novelty of LIGHT, we also measured 59 inflammation or inflammasome biomarkers. This study highlights the significant roles of LIGHT and IL-18 in the severity of sepsis and for the first time, we demonstrate a key damaging role of LIGHT in patients with sepsis complicated by ARDS or multi-organ failures.

\section{Research Design and Methods}

Subjects: The patient case cohort presented here is derived from a sepsis cohort study $^{28,29}$, employing 280 sepsis cases, including 189 contiguously enrolled $(67.5 \%)$ cases diagnosed with bacterial sepsis between 2016 - 2017 (either culture proven or presumed based on clinical presentation) and a nested cohort of $91(32.5 \%)$ cases diagnosed with PCR-confirmed viral sepsis between 2014 and 2019 (Table 1), compared with 22 random population based controls. For sepsis cases, we obtained residual plasma from the blood collected clinically in the emergency room or on admission to the intensive care unit for subjects transferred from the floor and termed this "day 0 plasma." The clinical protocol is to spin citrated vacutainers upon receipt and to keep the plasma at 4 degrees after centrifuging; our research team collected the plasma at $12-36$ hours after centrifuge, aliquoted, and froze the plasma at $-80^{\circ} \mathrm{C}$ until assay.

The classification of ARDS required meeting oxygen and radiographic Berlin definition criteria on the same calendar day while receiving invasive ventilation ${ }^{30}$. We defined acute hypoxic respiratory failure (AHRF) as the patient manifesting hypoxia with arterial oxygen tension relative to fraction of inspired oxygen $\left(\mathrm{PaO}_{2}: \mathrm{FiO}_{2}\right.$ or $\mathrm{PF}$ ratio $) \leq 300$ with or without mechanical ventilation. The determination of AKI was made in patients without preexisting end stage renal disease, based on serum creatinine and urine output using the Kidney Disease Improving Global Outcomes (KDIGO) guidelines ${ }^{31}$. The APACHE III scoring was as described by Knaus et al., as previously reported $^{32}$.

Among the patients with culture or PCR proven viral sepsis, 56(61.5\%) had influenza; 10(11.0\%) had respiratory syncytial virus (RSV); 7(7.7\%) had Human metapneumovirus (hMPV); 4(4.4\%) had adenoviruses; 4(4.4\%) had non-COVID-19 coronavirus; 4(4.4\%) had parainfluenza; and 6 $(6.6 \%)$ had other viruses. Of those, 36(39.6\%) developed ARDS; 50(55.6\%) developed AHRF; 49(53.8\%) manifested AKI; and $32(35.2 \%)$ had both (ARDS or AHRF) and AKI.

Among the bacterial sepsis patients,35\% of culture proven cases were gram positive bacteria (most commonly Streptococcus, Staphylococcus, Enterococcus, and Gram-Positive Rod) and 55\% were due to gram negative bacteria (most commonly Escherichia coli, Pseudomonas aeruginosa, Klebsiella pneumoniae, Acinetobacter baumannii, and gram-negative rod). Of those, 65 (34.4\%) were diagnosed with ARDS; 71(37.8\%) were diagnosed with acute hypoxic respiratory failure (AHRF); 114 (61.6\%) were diagnosed with AKI; and 49 (25.9\%) had both (ARDS or AHRF) and AKI.

Measurement of circulating cytokines: Our primary analysis was to test the association of plasma LIGHT with organ failures. LIGHT was measured by the Quanterix high sensitivity single molecular array technology (Myriad RBM Simoa ${ }^{\mathrm{TM}}$ Services, Austin, TX) as a customized 
medRxiv preprint doi: https://doi.org/10.1101/2021.05.25.21257799; this version posted May 27, 2021. The copyright holder for this preprint (which was not certified by peer review) is the author/funder, who has granted medRxiv a license to display the preprint in perpetuity.

All rights reserved. No reuse allowed without permission.

addition to the Human Inflammation MAP® v. 1.1. IL-18 is a LIGHT-like proinflammatory cytokine we have an opportunity to modulate with an anti-IL18 neutralizing mAb and as such a cytokine of special interest to us and was analyzed as the first and only mediator of the Myriad multiplex panel measures. Because the Myriad system employs multiplex technology, we had the opportunity to contextualize LIGHT and IL-18 values with an additional 59 biomarkers (cytokines, chemokines and acute-phase reactants included in the Human Inflammation MAP® v. 1.1, plus extra 14 custom biomarkers) which were considered secondary measures. LIGHT and other biomarkers were also measured at the same time in 22 samples from a random deidentified dataset of healthy (population based) subjects within comparable age, sex and ethnic background to the sepsis cases. The list of the biomarkers measured is shown in Supplementary Table 1.

Data analysis: The plasma levels of the measured biomarkers were normalized by natural $\log$ transformation for further analysis. Elevated LIGHT level was defined as $>2$ standard deviations (SD) above mean in reference controls. Statistical analysis, including independent-samples t-test, One-Way ANOVA test, bivariate correlations, and non-parametric Chi-square test, were done by the IBM SPSS Statistics Version 23 software.

The study was approved by the Institutional Review Boards of The University of Pennsylvania. Written informed consent was obtained from each participating subject or their proxy.

\section{Results}

\section{Increased plasma LIGHT levels in patients with sepsis}

Increased LIGHT levels were observed in the sepsis cohort of 280 patients overall, compared to control levels from random adult samples, and this was attributed to increased LIGHT levels in both the bacterial and viral subsets of sepsis (independent t-test, Table 2). LIGHT levels were found to correlate inversely with age $(r=-0.120, p=0.045)$, i.e. older age correlated with lower levels of LIGHT, whereas sex, race and BMI did not show correlation with LIGHT levels. Patients with viral sepsis showed trend of having lower LIGHT levels than patients with bacterial sepsis, though not statistically different $(\mathrm{P}=0.060)$. In addition, as shown in Table 5, several other biomarkers demonstrated association with organ failure in the overall sepsis group, including both bacterial and viral sepsis.

Overall, we observed increased LIGHT levels in both bacterial and viral sepsis patients (Figure 1, Table 2). We defined abnormal LIGHT levels as higher than 2 times of standard deviation of the reference controls. In the 91 patients with viral sepsis, 12 (13.2\%) cases had increased LIGHT. In the 189 bacterial sepsis cases, 40 (21.2\%) cases had increased LIGHT, and 1/22 (4.5\%) controls had elevated LIGHT. Overall, binary increased LIGHT was associated with AHRF with $\mathrm{r}=0.123$, $\mathrm{P}=0.043$, and trend towards elevated Apache III score with $\mathrm{r}=0.114, \mathrm{P}=0.060$, also associating with age. However, this analysis is underpowered.

- In the viral sepsis cases, the Apache III scores were lower compared to bacterial sepsis, fewer patients had elevated LIGHT and correlation of LIGHT with Apache III score, ARDS, AHRF, AKI, and mortality, was not significant. Borderline significance was seen between increased length of ICU/hospital stay (LOS) and elevated LIGHT ( $\mathrm{r}=0.207$, $\mathrm{P}=0.052$ ). 
medRxiv preprint doi: https://doi.org/10.1101/2021.05.25.21257799; this version posted May 27, 2021. The copyright holder for this preprint (which was not certified by peer review) is the author/funder, who has granted medRxiv a license to display the preprint in perpetuity.

All rights reserved. No reuse allowed without permission.

- In contrast, in the bacterial sepsis cases, elevated LIGHT was correlated with Apache III, with $\mathrm{r}=0.172, \mathrm{p}=0.020$; associated with $\mathrm{ARDS}$, with $\mathrm{OR}(95 \% \mathrm{CI})=2.180(1.077,4.414)$, $\mathrm{p}=0.028$; associated with AHRF, with $\mathrm{OR}(95 \% \mathrm{CI})=2.037(1.011,4.106), \mathrm{p}=0.044$; and associated with AKI, with $\mathrm{OR}(95 \% \mathrm{CI})=2.179(0.991,4.791), \mathrm{p}=0.049$ (Table 3). In addition, we also observed inverse correlation between LIGHT concentrations and LOS $(\mathrm{r}=-0.153, \mathrm{p}=0.039)$.

Taken together, these results suggest that LIGHT may be a stronger pathogenic driver in bacterial sepsis than in viral sepsis, and given that both Apache III scores and mortality rates were higher in the bacterial sepsis lend support for elevated Apache III scores be considered an approach to identify patients that may have most benefit from LIGHT neutralizing mAb therapy.

\section{Variable plasma IL-18 levels in patients with sepsis}

We observed a wide dynamic range of IL-18 plasma concentrations, from 80 to $>32,400 \mathrm{pg} / \mathrm{mL}$ in bacterial sepsis; and 161 to $19,100 \mathrm{pg} / \mathrm{mL}$ in viral sepsis. Compared to plasma LIGHT levels, the increase of plasma IL-18 levels showed only nominal significance in patients with sepsis (Table 2). In our study, sex, age, and BMI did not show correlation with IL-18 levels. However, IL-18 levels were found to correlate with self-identified race, with African American subjects manifesting lower IL-18 levels than other populations $(6.44 \pm 0.98 v s .6 .79 \pm 0.85, \mathrm{p}=0.003)$. In this case, instead of defining abnormal IL-18 levels, we tested association of quantitative IL-18 levels with clinical phenotypes, controlled for race (Table 4). Overall, IL-18 levels were correlated with Apache III scores, mortality, and AKI, with highly significant $\mathrm{p}$ values; and correlated with AHRF and ARDS with nominal significance. In addition, the correlation of IL-18 with Apache III scores, mortality, and AKI, were consistently observed in both bacterial sepsis and viral sepsis. In contrast, the correlation of IL-18 with AHRF was only observed in viral sepsis. These results suggest that, unlike LIGHT with prominent effects mainly observed in bacterial sepsis, IL-18 has significant impact in both bacterial and viral sepsis.

\section{Exploratory analysis of 59 biomarkers in sepsis}

(1) Exploratory biomarkers associated with Apache III score in both bacterial and viral sepsis cases

Among the 59 exploratory biomarkers tested (i.e., markers other than LIGHT and IL-18), Tissue Inhibitor of Metalloproteinases 1 (TIMP-1), Tumor necrosis factor receptor 2 (TNFR2), Vascular Cell Adhesion Molecule-1 (VCAM-1), Plasminogen Activator Inhibitor 1 (PAI-1), IL-18 Binding Protein (IL-18BP), myoglobin, Interleukin-6 (IL-6), von Willebrand Factor (vWF), Interleukin-8 (IL-8), ferritin (FRTN), Interleukin-1 receptor antagonist (IL-1Ra), Matrix Metalloproteinase-3 (MMP-3), Interleukin-10 (IL-10), Eotaxin-1, Macrophage Inflammatory Protein-1 $\beta$ (MIP-1 $\beta$ ) and Interleukin-1 $\beta$ (IL-1 $\beta$ ), were positively correlated with Apache III, in both bacterial and viral sepsis (Table 5).

Interestingly, complement C3, Factor VII, Vitamin D-Binding Protein (VDBP), ThyroxineBinding Globulin (TBG), Serum Amyloid P-Component (SAP), Fibrinogen, and T-Cell-Specific Protein RANTES (RANTES), were all negatively correlated with Apache III score in both bacterial and viral sepsis (Table 5). 
medRxiv preprint doi: https://doi.org/10.1101/2021.05.25.21257799; this version posted May 27, 2021. The copyright holder for this preprint (which was not certified by peer review) is the author/funder, who has granted medRxiv a license to display the preprint in perpetuity. All rights reserved. No reuse allowed without permission.

(2) Exploratory biomarkers associated with ARDS and AHRF in both bacterial and viral sepsis

In addition to the correlation of LIGHT and IL-18 as shown above, among the 59 exploratory biomarkers, PAI-1 was positively correlated with ARDS and AHRF, whereas fibrinogen was negatively correlated with ARDS (Table 5). Interestingly, another exploratory observation in patients with sepsis is that, IL-10, IL-6, IL-1Ra, IL-8, and TIMP-1, are associated with ARDS and AHRF in viral sepsis only at highly statistical significance. No such association was identified with bacterial sepsis in this study.

(3) Exploratory biomarkers associated with AKI in both bacterial and viral sepsis

In addition to the association of LIGHT and IL, among the 60 additional biomarkers, B2M, Stem Cell Factor (SCF), TNFR2, VCAM-1, TIMP-1, Myoglobin, MMP-3, PAI-1, IL-18 and IL-18BP, were positively correlated with AKI, indicative of worse clinical outcome (Table 5).

(4) Exploratory biomarkers associated with elevated LIGHT levels

In viral sepsis, elevated LIGHT was positively correlated with RANTES. In bacterial sepsis, LIGHT was positively correlated with TIMP-1, TNFR2, PAI-1, IL-1Ra, vWF, IL-18BP, and B2M, while it was negatively correlated with Factor VII (Table 5). The above associations of LIGHT with these disease associated biomarkers are in keeping with the effects of LIGHT that we have observed in association with severe bacterial sepsis and its complications.

(5) Exploratory biomarkers associated with IL-18 levels

IL-18 levels correlated with disease biomarkers in both bacterial and viral sepsis. In both bacterial and viral sepsis, IL-18 levels were positively correlated with Ferritin, IL-10, IL-18BP, PAI-1, TIMP-1, TNFR2, VCAM-1, IL-8, MIP-1 $\beta$, vWF, IL-1Ra, IL-6, B2M, and SCF; and negatively correlated with RANTES, Lp(a), and C3. In bacterial sepsis, IL-18 levels were also positively correlated with Eotaxin-1 and MMP-3; and negatively correlated with Factor VII and Fibrinogen. In viral sepsis, IL-18 levels were also negatively correlated with SAP and VDBP. IL18 levels were not correlated with elevated LIGHT levels in either bacterial or viral sepsis (Table $5)$.

\section{Discussion}

\section{LIGHT and IL-18 levels as biomarkers in sepsis}

In this study, we report elevated LIGHT levels in both bacterial and viral sepsis and association of LIGHT with ARDS and multi-organ failures in bacterial sepsis patients, including extended length of hospitalization, increased sepsis severity and sepsis complications. The lack of correlation of LIGHT in viral sepsis with Apache III score, ARDS, AHRF, and AKI is likely a reflection of smaller sample size $(n=91)$. As shown here, viral sepsis cases had higher prevalence of ARDS and AHRF than bacterial sepsis, and both were significantly correlated with increased levels of the pro-inflammatory cytokines IL-10, IL-6, and IL-8, as well as the acute phase protein IL-1Ra, and the matrix metalloproteinases (MMPs) inhibitor TIMP- $1^{33}$. However, these 
medRxiv preprint doi: https://doi.org/10.1101/2021.05.25.21257799; this version posted May 27, 2021. The copyright holder for this preprint (which was not certified by peer review) is the author/funder, who has granted medRxiv a license to display the preprint in perpetuity.

All rights reserved. No reuse allowed without permission.

biomarkers were not correlated with LIGHT levels in either bacterial or viral sepsis. Endogenously produced IL-10 has been shown as a major mediator of septic injuries in lung antibacterial immune defense ${ }^{34}$, while IL-6, and IL-8, are pro-inflammatory cytokines involved in acute inflammation ${ }^{35}$. IL-1Ra is an acute phase protein with potential anti-inflammatory effect by binding to IL-1 receptors ${ }^{36}$. Among these cytokines/biomarkers, the strongest correlation with ARDS/AHRF was from IL-10, suggesting ARDS/AHRF is a complex biological condition involving both anti-inflammatory and pro-inflammatory mediators ${ }^{37}$.

IL-18 is a proinflammatory cytokine, inducing the production of interferon- $\gamma(\text { IFN } \gamma)^{38}$. Previous study has suggested IL-1 and IL-18 as potential therapeutic targets due to their crucial roles in sepsis ${ }^{5}$. In our study, while IL-1 $\alpha$ and IL-1 $\beta$ were also measured, only IL-18 levels were consistently observed for correlations with increased sepsis severity and sepsis complications in both bacterial and viral sepsis. Highly significant associations were observed between IL-18 and TIMP-1, the pro-inflammatory cytokines IL-6, and IL-8, the injury mediator IL10, and the antiinflammatory mediator IL1ra, all of which were observed in both bacterial and viral sepsis. Given the large variance of plasma IL-18 among septic subjects with its extensive associations with disease biomarkers, targeting this pathway raises opportunities that require a precision application. In our study, IL-18 levels weren't correlated with elevated LIGHT levels in either bacterial or viral sepsis, suggesting independent effects of LIGHT and IL-18 in sepsis rendering a combination therapy with neutralizing antibodies to LIGHT and IL18 a feasible choice.

\section{Mechanistic insights from Apache III score biomarkers}

In bacterial sepsis, LIGHT is correlated with Apache III scores, AHRF and multi-organ failures, including ARDS and AKI, as well as length of hospital stay. The observed association of elevated LIGHT in organ failures are consistently observed to be associated with other biomarkers of organ failures, suggesting LIGHT may be a driver of inflammation through its induction of the expression and action of various other mediators ${ }^{17}$. In bacterial sepsis, LIGHT is associated with other biomarkers of increased Apache III score, including TIMP-1, TNFR2, PAI-1, IL-1Ra, vWF, IL-18BP, and B2M. Unanimously, LIGHT is negatively correlated with biomarkers that are associated with decreased Apache III score, including Factor VII. Among these biomarkers, PAI1 is also correlated with increased risk of ARDS and AHRF; TIMP-1, TNFR2, PAI-1, IL-18BP, and $\mathrm{B} 2 \mathrm{M}$ are also correlated with increased risk of AKI.

The association of increased LIGHT level and Apache III score in bacterial sepsis observed in this study may be explained in part by the association of LIGHT with increased risk of ARDS, AHRF, and AKI, as discussed above. In addition to the correlation of other ARDS/AHRF and AKI biomarkers with LIGHT levels, LIGHT was also positively correlated with the Apache III score biomarkers, IL-1Ra and vWF in the bacterial sepsis cases. Previous study has shown that IL-1Ra is significantly associated with activation markers of coagulation, plasma levels of prothrombin fragment 1 and fragment $2(\mathrm{~F} 1+2)$, in severe infection ${ }^{39}$. vWF plays a major role in blood coagulation by causing vWF-dependent platelet adhesion ${ }^{40}$. In bacterial sepsis, elevated LIGHT is not correlated with the Apache III score biomarker, IL-10 levels. Multivariate linear regression analysis of Apache III score shows independent effects of the exploratory biomarker, IL-10 (standardized coefficient Beta=0.199, $\mathrm{p}=0.005$ ) and elevated LIGHT (standardized coefficient Beta $=0.144, \mathrm{p}=0.039$ ), controlled for age, suggesting that LIGHT effects are independent of IL-10 mediated effects, such as cytokine storming in bacterial sepsis. This 
medRxiv preprint doi: https://doi.org/10.1101/2021.05.25.21257799; this version posted May 27, 2021. The copyright holder for this preprint (which was not certified by peer review) is the author/funder, who has granted medRxiv a license to display the preprint in perpetuity.

All rights reserved. No reuse allowed without permission.

LIGHT effect was not seen in viral sepsis besides IL-10 effects. In addition, LIGHT is negatively correlated with various protective biomarker in sepsis, including Factor VII. Acquired factor VII deficiency is associated with severe systemic sepsis ${ }^{41}$.

In both bacterial and viral sepsis, IL-18 is significantly correlated with Apache III score with high significance. In addition to the above biomarkers and related mechanisms shared by LIGHT, IL-18 is consistently correlated with TIMP-1, proinflammatory IL-10, IL-6, and IL-8. TIMP-1 is a key regulator of degradation of extracellular matrix. The matrix metalloproteinases (MMPs) degrade extracellular matrix and TIMP-1 is a natural inhibitor of MMPs ${ }^{42}$. TIMP-1 also promotes cell proliferation and has anti-apoptotic function ${ }^{43}$. In addition, IL-18 was consistently negatively correlated with protective biomarkers, RANTES, Lp(a), and C3, in both bacterial and viral sepsis. Among these biomarkers negatively associated with Apache III score, LIGHT was correlated with increased RANTES in viral sepsis. As shown previously, LIGHT is thought to induce the expression of RANTES through the lymphotoxin $\beta$ receptor (LT $\beta$ R) signaling ${ }^{44}$. Unlike LIGHT, IL-18 was correlated with decreased RANTES levels in both bacterial and viral sepsis. Of note, RANTES is a chemokine with recognized pleiotropic activities, e.g. the beneficial effect of recruiting immune cells to areas of infection and the potential detrimental effects of enhancing the inflammatory processes ${ }^{45}$. $\mathrm{Lp}(\mathrm{a})$ is the major protein component of HDL. HDL has anti-inflammatory properties and is diminished during inflammation ${ }^{46}$, which depletes $\mathrm{Lp}(\mathrm{a})$ in severe sepsis ${ }^{47}$. Complement depletion represented by decreased C 3 also contributes to severe sepsis $^{48}$.

\section{Plasminogen Activator Inhibitor 1 (PAI-1) as supportive mediator to that of LIGHT and IL-18 in ARDS and AHRF}

PAI-1 levels show significant correlation with ARDS and AHRF are also positively correlated with LIGHT levels in bacterial sepsis; and positively correlated with IL-18 levels in both bacterial and viral sepsis. PAI-1 is the main physiological plasminogen activator inhibitor, which is critical for regulating the fibrinolytic system and maintaining normal hemostasis ${ }^{49}$. Disseminated intravascular coagulation (DIC) is an important pathogenesis in early stage of acute lung injury (ALI) and ARDS ${ }^{50}$. Due to the crucial role of the fibrinolytic system and DIC in the pathophysiology of sepsis, PAI-1 levels have been shown to be important prognostic biomarker in sepsis ${ }^{51}$. Elevated in lung injury, alveolar PAI-1 levels can also predict ARDS in aspiration pneumonitis ${ }^{52}$. Encoded by the serpin family E member 1 gene (SERPINE1), the expression of PAI- 1 is upregulated by LIGHT ${ }^{53}$. Therefore, the highly significant correction between LIGHT levels and PAI-1 levels identified by this study suggests that LIGHT may contribute to ARDS/AHRF in sepsis by increasing the PAI-1 levels.

\section{Mechanistic insights from biomarkers associated with AKI}

LIGHT levels in bacterial sepsis and IL-18 in both bacterial and viral sepsis were positively correlated with the ARDS/AHRF biomarkers, TIMP-1, TNFR2, PAI-1, IL-18BP, and B2M. B2M is a marker of proximal tubular injury in $\mathrm{AKI}^{54}$. While PAI-1 suppresses fibrinolysis in DIC, TIMP-1 has also been suggested to play a role in the coagulation disturbance and disease severity of DIC ${ }^{55}$. TNFR2 is the second receptor of the cytokines TNF and lymphotoxin- $\alpha$, shown to mediate both proinflammatory and anti-inflammatory effects ${ }^{56}$. In recent years, TNFR2 has attracted research attentions as an emerging drug target for autoimmune diseases and 
medRxiv preprint doi: https://doi.org/10.1101/2021.05.25.21257799; this version posted May 27, 2021. The copyright holder for this preprint (which was not certified by peer review) is the author/funder, who has granted medRxiv a license to display the preprint in perpetuity.

All rights reserved. No reuse allowed without permission.

cancer $^{57}$. In sepsis, TNFR2 has been shown to associate with CD4+ T-cell impairment and postseptic immunosuppression by activation of regulatory T cells (Treg) ${ }^{58}$. Renal-expressed TNFR2 promotes renal monocyte recruitment by the IRF1 and IFN- $\beta$ autocrine signaling, and may lead to renal injury ${ }^{59}$. IL-18BP is the specific inhibitor of IL-18, and neutralizes IL-18 activities ${ }^{38}$. Previous study has shown that IL-18 mediates ischemic acute tubular necrosis in AKI ${ }^{60}$, whereas our study shows that IL-18BP has much stronger correlation with AKI than IL-18 in sepsis.

In conclusion, this study demonstrates independent associations of LIGHT and IL-18 in septic organ failures. Our study highlights two potential therapeutic targets in sepsis, i.e. the significantly increased LIGHT levels and the highly variable IL-18 levels across a subset of patients with sepsis. The detrimental roles of LIGHT in multi-organ failures were mainly seen in bacterial sepsis, including ARDS/AHRF, AKI, and its association with higher Apache III score as well as length of hospital stay with significant trend towards higher mortality rates. Consistently, the detrimental effects of LIGHT in bacterial sepsis were supported by the correlations of LIGHT with other biomarkers of organ failure suggesting a key role for LIGHT as an inflammatory driver of other detrimental mediators ${ }^{61}$. Given that LIGHT presents an interesting therapeutic target for severe inflammatory conditions, our results suggest for the first time that anti-LIGHT therapy with neutralizing $\mathrm{mAb}$ may be effective in a subset of patients with sepsis unrelated to COVID-19 infections. In contrast, IL-18 was associated with the detrimental outcome of both bacterial and viral sepsis, including increased mortality, and additionally supported by the correlations of IL-18 with other biomarkers involved with organ failure. The observed significant variance in IL-18 levels between individuals with sepsis highlights its potential as a precision therapeutic target with neutralizing $\mathrm{mAb}$, by selecting patients with significantly elevated IL-18. The lack of correlation between LIGHT and IL-18 levels, as well as different correlations with other biomarkers, suggests independent and distinct roles of LIGHT and IL-18 in sepsis and that therapy directed against both of these cytokines should be given a consideration.

\section{Declaration of Conflicting Interests}

Dr. Hakonarson and CHOP own stock in Cerecor. Drs. Meyer and Reilly are or have been site investigators for ARDS and sepsis clinical trials unrelated to the present work (sponsored by Quantum Leap Healthcare Collaborative; Athersys, Inc; Biomarck, Inc; and the Marcus Foundation). The authors declare no other potential conflicts of interest with respect to the research, authorship, and/or publication of this article.

\section{Ethical Approval}

This study was approved by the University of Pennsylvania Institutional Review Board (IRB), protocol \#808542. All human subjects or their proxies provided written informed consent.

\section{Funding}

The study was supported by:

UPENN funding: The sepsis cohort study is supported by NIH HL137006 and HL137915 (Meyer).

Cerecor funding: Sponsored research by Cerecor funded LIGHT and other biomarker measures. 
medRxiv preprint doi: https://doi.org/10.1101/2021.05.25.21257799; this version posted May 27, 2021. The copyright holder for this preprint (which was not certified by peer review) is the author/funder, who has granted medRxiv a license to display the preprint in perpetuity. All rights reserved. No reuse allowed without permission.

CHOP funding: Institutional Development Funds from the Children's Hospital of Philadelphia to the Center for Applied Genomics, The Children's Hospital of Philadelphia Endowed Chair in Genomic Research (HH).

\section{Figure Legend}

Figure 1. Increased Ln(LIGHT) levels in bacterial and viral sepsis. 


\section{Reference:}

1. Croft M, Siegel RM. Beyond TNF: TNF superfamily cytokines as targets for the treatment of rheumatic diseases. Nature Reviews Rheumatology. 2017;13(4):217.

2. Steinberg MW, Cheung TC, Ware CF. The signaling networks of the herpesvirus entry mediator (TNFRSF14) in immune regulation. Immunological reviews. 2011;244(1):169-187.

3. Ware CF, Šedý JR. TNF Superfamily Networks: bidirectional and interference pathways of the herpesvirus entry mediator (TNFSF14). Current opinion in immunology. 2011;23(5):627-631.

4. Wynn JL, Wilson CS, Hawiger J, et al. Targeting IL-17A attenuates neonatal sepsis mortality induced by IL-18. Proceedings of the National Academy of Sciences. 2016;113(19):E2627-E2635.

5. Berghe TV, Demon D, Bogaert P, et al. Simultaneous targeting of IL-1 and IL-18 is required for protection against inflammatory and septic shock. American journal of respiratory and critical care medicine. 2014;189(3):282-291.

6. Dolinay T, Kim YS, Howrylak J, et al. Inflammasome-regulated cytokines are critical mediators of acute lung injury. Am J Respir Crit Care Med. 2012;185(11):1225-1234.

7. Remick DG. Pathophysiology of Sepsis. The American Journal of Pathology. 2007;170(5):1435-1444.

8. Singer M, Deutschman CS, Seymour CW, et al. The Third International Consensus Definitions for Sepsis and Septic Shock (Sepsis-3). Jama. 2016;315(8):801-810.

9. Mikkelsen ME, Shah CV, Meyer NJ, et al. The epidemiology of acute respiratory distress syndrome in patients presenting to the emergency department with severe sepsis. Shock. 2013;40(5):375-381.

10. Bagshaw SM, George C, Bellomo R. Early acute kidney injury and sepsis: a multicentre evaluation. Critical care (London, England). 2008;12(2):R47.

11. Levi M, van der Poll T. Coagulation and sepsis. Thrombosis Research. 2017;149:38-44.

12. Strieter R, Lynch 3rd J, Basha M, Standiford T, Kasahara K, Kunkel S. Host responses in mediating sepsis and adult respiratory distress syndrome. Paper presented at: Seminars in respiratory infections 1990.

13. Fry DE. Sepsis, systemic inflammatory response, and multiple organ dysfunction: the mystery continues. The American Surgeon. 2012;78(1):1-8.

14. Mauri DN, Ebner R, Montgomery RI, et al. LIGHT, a new member of the TNF superfamily, and lymphotoxin alpha are ligands for herpesvirus entry mediator. Immunity. 1998;8(1):21-30.

15. del Rio ML, Lucas CL, Buhler L, Rayat G, Rodriguez-Barbosa JI. HVEM/LIGHT/BTLA/CD160 cosignaling pathways as targets for immune regulation. Journal of leukocyte biology. 2010;87(2):223-235.

16. Cheung TC. Modulation of T cell proliferation through the LIGHT-HVEM-BTLA cosignaling pathway. Recent patents on DNA \& gene sequences. 2009;3(3):177-182.

17. Celik S, Shankar V, Richter A, et al. Proinflammatory and prothrombotic effects on human vascular endothelial cells of Immune-cell-derived LIGHT. European Journal of Medical Research. 2009;14(4):147.

18. Vasarmidi E, Tsitoura E, Spandidos DA, Tzanakis N, Antoniou KM. Pulmonary fibrosis in the aftermath of the COVID-19 era. Experimental and therapeutic medicine. 2020;20(3):2557-2560.

19. Perlin DS, Zafir-Lavie I, Roadcap L, Raines S, Ware CF, Neil GA. Levels of the TNF-Related Cytokine LIGHT Increase in Hospitalized COVID-19 Patients with Cytokine Release Syndrome and ARDS. MSphere. 2020;5(4).

20. Arunachalam PS, Wimmers F, Mok CKP, et al. Systems biological assessment of immunity to mild versus severe COVID-19 infection in humans. Science. 2020;369(6508):1210-1220.

21. Haljasmägi L, Salumets A, Rumm AP, et al. Longitudinal proteomic profiling reveals increased early inflammation and sustained apoptosis proteins in severe COVID-19. Scientific reports. 2020;10(1):1-12.

22. Patel S, Saxena B, Mehta P. Recent updates in the clinical trials of therapeutic monoclonal antibodies targeting cytokine storm for the management of COVID-19. Heliyon. 2021:e06158.

23. Cheng T, Bai J, Chung C-S, Chen Y, Fallon EA, Ayala A. Herpes virus entry mediator (HVEM) expression promotes inflammation/organ injury in response to experimental indirect-acute lung injury. Shock (Augusta, Ga). 2019;51(4):487.

24. Baker KJ, Houston A, Brint E. IL-1 Family Members in Cancer; Two Sides to Every Story. Front Immunol. 2019;10:1197.

25. Fabbi M, Carbotti G, Ferrini S. Context-dependent role of IL-18 in cancer biology and counter-regulation by IL-18BP. Journal of leukocyte biology. 2015;97(4):665-675.

26. Yu S, Chen Z, Mix E, et al. Neutralizing antibodies to IL-18 ameliorate experimental autoimmune neuritis by counter-regulation of autoreactive Th1 responses to peripheral myelin antigen. Journal of Neuropathology \& Experimental Neurology. 2002;61(7):614-622. 
27. Dinarello C, Novick D, Kim S, Kaplanski G. Interleukin-18 and IL-18 Binding Protein. Frontiers in Immunology. 2013;4(289).

28. Reilly JP, Anderson BJ, Hudock KM, et al. Neutropenic sepsis is associated with distinct clinical and biological characteristics: a cohort study of severe sepsis. Critical care (London, England). 2016;20(1):222.

29. Reilly JP, Wang F, Jones TK, et al. Plasma angiopoietin-2 as a potential causal marker in sepsis-associated ARDS development: evidence from Mendelian randomization and mediation analysis. Intensive care medicine. 2018;44(11):1849-1858.

30. Ranieri VM, Rubenfeld GD, Thompson BT, et al. Acute respiratory distress syndrome: the Berlin Definition. Jama. 2012;307(23):2526-2533.

31. Kellum JA, Lameire N, Aspelin P, et al. Kidney disease: improving global outcomes (KDIGO) acute kidney injury work group. KDIGO clinical practice guideline for acute kidney injury. Kidney international supplements. 2012;2(1):1-138.

32. Knaus WA, Wagner DP, Draper EA, et al. The APACHE III prognostic system: risk prediction of hospital mortality for critically III hospitalized adults. Chest. 1991;100(6):1619-1636.

33. Visse R, Nagase H. Matrix metalloproteinases and tissue inhibitors of metalloproteinases: structure, function, and biochemistry. Circulation research. 2003;92(8):827-839.

34. Steinhauser ML, Hogaboam CM, Kunkel SL, Lukacs NW, Strieter RM, Standiford TJ. IL-10 is a major mediator of sepsis-induced impairment in lung antibacterial host defense. The Journal of Immunology. 1999;162(1):392-399.

35. Bester J, Pretorius E. Effects of IL-1 $\beta$, IL-6 and IL-8 on erythrocytes, platelets and clot viscoelasticity. Scientific Reports. 2016;6(1):32188.

36. Arend WP, Malyak M, Guthridge CJ, Gabay C. Interleukin-1 receptor antagonist: role in biology. Annual review of immunology. 1998;16:27-55.

37. Lu L, Zhang H, Dauphars DJ, He Y-W. A Potential Role of Interleukin-10 in COVID-19 Pathogenesis. Trends in Immunology. 2020.

38. Dinarello CA. Interleukin-18 and the pathogenesis of inflammatory diseases. Seminars in nephrology. 2007;27(1):98-114.

39. Suharti C, van Gorp EC, Setiati TE, et al. The role of cytokines in activation of coagulation and fibrinolysis in dengue shock syndrome. Thrombosis and haemostasis. 2002;87(01):42-46.

40. $\quad$ Ruggeri ZM. von Willebrand factor. The Journal of clinical investigation. 1997;99(4):559-564.

41. Biron C, Bengler C, Gris J, Schved J. Acquired isolated factor VII deficiency during sepsis. Pathophysiology of Haemostasis and Thrombosis. 1997;27(2):51-56.

42. Wojtowicz-Praga SM, Dickson RB, Hawkins MJ. Matrix metalloproteinase inhibitors. Investigational new drugs. 1997;15(1):61-75.

43. Ando T, Charindra D, Shrestha M, et al. Tissue inhibitor of metalloproteinase-1 promotes cell proliferation through YAP/TAZ activation in cancer. Oncogene. 2018;37(2):263-270.

44. Yeh DY-W, Wu C-C, Chin Y-P, Lu C-J, Wang Y-H, Chen M-C. Mechanisms of human lymphotoxin beta receptor activation on upregulation of CCL5/RANTES production. International Immunopharmacology. 2015;28(1):220-229.

45. Levy JA. The Unexpected Pleiotropic Activities of RANTES. The Journal of Immunology. 2009;182(7):3945-3946.

46. Ansell BJ, Navab M, Watson KE, Fonarow GC, Fogelman AM. Anti-inflammatory properties of HDL. Reviews in Endocrine and Metabolic Disorders. 2004;5(4):351-358.

47. Van Leeuwen HJ, Heezius EC, Dallinga GM, van Strijp JA, Verhoef J, van Kessel KP. Lipoprotein metabolism in patients with severe sepsis. Critical care medicine. 2003;31(5):1359-1366.

48. Ward PA. Role of the complement in experimental sepsis. Journal of leukocyte biology. 2008;83(3):467470 .

49. LIJNEN HR. Pleiotropic functions of plasminogen activator inhibitor-1. Journal of Thrombosis and Haemostasis. 2005;3(1):35-45.

50. Gando S, Kameue T, Matsuda N, Sawamura A, Hayakawa M, Kato H. Systemic inflammation and disseminated intravascular coagulation in early stage of ALI and ARDS: role of neutrophil and endothelial activation. Inflammation. 2004;28(4):237-244.

51. Iba T, Thachil J. Clinical significance of measuring plasminogen activator inhibitor-1 in sepsis. $J$ Intensive Care. 2017;5:56-56.

52. El Solh AA, Bhora M, Pineda L, Aquilina A, Abbetessa L, Berbary E. Alveolar plasminogen activator inhibitor-1 predicts ARDS in aspiration pneumonitis. Intensive care medicine. 2006;32(1):110-115. 
53. Otterdal K, Andreassen AK, Yndestad A, et al. Raised LIGHT levels in pulmonary arterial hypertension: potential role in thrombus formation. American journal of respiratory and critical care medicine. 2008;177(2):202-207.

54. Barton KT, Kakajiwala A, Dietzen DJ, Goss CW, Gu H, Dharnidharka VR. Using the newer Kidney Disease: Improving Global Outcomes criteria, beta-2-microglobulin levels associate with severity of acute kidney injury. Clinical kidney journal. 2018;11(6):797-802.

55. Sivula M, Hästbacka J, Kuitunen A, et al. Systemic matrix metalloproteinase-8 and tissue inhibitor of metalloproteinases-1 levels in severe sepsis-associated coagulopathy. Acta anaesthesiologica Scandinavica. 2015;59(2):176-184.

56. Medler J, Wajant H. Tumor necrosis factor receptor-2 (TNFR2): an overview of an emerging drug target. Expert opinion on therapeutic targets. 2019;23(4):295-307.

57. Medler J, Wajant H. Tumor necrosis factor receptor-2 (TNFR2): an overview of an emerging drug target. Expert Opin Ther Targets. 2019;23(4):295-307.

58. Gaborit BJ, Roquilly A, Louvet C, et al. Regulatory T Cells Expressing Tumor Necrosis Factor Receptor Type 2 Play a Major Role in CD4+ T-Cell Impairment During Sepsis. The Journal of Infectious Diseases. 2020;222(7):1222-1234.

59. Venkatesh D, Ernandez T, Rosetti F, et al. Endothelial TNF receptor 2 induces IRF1 transcription factordependent interferon- $\beta$ autocrine signaling to promote monocyte recruitment. Immunity. 2013;38(5):10251037.

60. Melnikov VY, Faubel S, Siegmund B, Lucia MS, Ljubanovic D, Edelstein CL. Neutrophil-independent mechanisms of caspase-1- and IL-18-mediated ischemic acute tubular necrosis in mice. The Journal of clinical investigation. 2002;110(8):1083-1091.

61. Shui JW, Steinberg MW, Kronenberg M. Regulation of inflammation, autoimmunity, and infection immunity by HVEM-BTLA signaling. Journal of leukocyte biology. 2011;89(4):517-523. 
medRxiv preprint doi: https://doi.org/10.1101/2021.05.25.21257799; this version posted May 27, 2021. The copyright holder for this preprint (which was not certified by peer review) is the author/funder, who has granted medRxiv a license to display the preprint in perpetuity.

All rights reserved. No reuse allowed without permission.

Table 1 Clinical characteristics of the research subjects

\begin{tabular}{|l|l|l|}
\hline $\begin{array}{l}\text { Clinical } \\
\text { Information }\end{array}$ & Bacterial Sepsis & Viral Sepsis \\
\hline $\begin{array}{l}\text { Age (median, 1 } \\
\text { and } \mathbf{3}^{\text {rd }} \text { quartiles) }\end{array}$ & $61.5(52.1,71.4)$ & $61(52.5,69)$ \\
\hline sex & $\begin{array}{l}111(58.7 \%) \quad \text { males; 78(41.3\%) } \\
\text { females }\end{array}$ & $\begin{array}{l}51(56.0 \%) \\
\text { females }\end{array}$ \\
\hline BMI (x $\square \pm \mathbf{s})$ & $27.05 \pm 7.70$ & $27.59 \pm 7.37$ \\
\hline race & $\begin{array}{l}\text { White: 121; Black: 57; Asian: 8; } \\
\text { Native American: 1; Other: 2 }\end{array}$ & $\begin{array}{l}\text { White: 55; Black: 31; Asian: 2; } \\
\text { Other: 3 }\end{array}$ \\
\hline ARDS & Yes: 65(34.4\%); No: 124(65.6\%) & Yes: 36(39.6\%); No: 55(60.4\%) \\
\hline AHRF & Yes: 71(37.8\%); No: 117(62.2\%) & Yes: 50(55.6\%); No: 40(44.4\%) \\
\hline AKI & Yes: 114(61.6\%); No: 71(38.4\%) & Yes: 49(53.8\%); No: 42(46.2\%) \\
\hline APACHE III & $101.6 \pm 36.9$ & $90.8 \pm 39.4$ \\
\hline LOS & $19.38 \pm 20.78$ & $17.70 \pm 19.98$ \\
\hline Mortality & Yes: 77(40.7\%); No: 112(59.3\%) & Yes: 33(36.3\%); No: 58(63.7\%) \\
\hline
\end{tabular}

Table 2 Ln(LIGHT) and Ln(IL-18) levels in bacterial and viral sepsis

\begin{tabular}{|l|l|l|l|l|l|}
\hline Group & $\mathbf{n}$ & $\mathbf{L n}(\mathbf{L I G H T})$ & & $\mathbf{L n}(\mathbf{I L - 1 8})$ & \\
\hline Sepsis & 189 & $\mathbf{x} \square \pm \mathbf{S}$ & $\mathbf{P}$ & $\mathbf{x} \square \pm \mathbf{S}$ & $\mathbf{P}$ \\
\hline $\begin{array}{l}\text { reference } \\
\text { controls }\end{array}$ & 22 & $3.76 \pm 0.64$ & $\begin{array}{l}1.80 \mathrm{E}- \\
05\end{array}$ & $6.71 \pm 0.91$ & 0.038 \\
\hline $\begin{array}{l}\text { Viral } \\
\text { infection }\end{array}$ & 91 & $4.29 \pm 0.72$ & $\begin{array}{l}1.78 \mathrm{E}- \\
03\end{array}$ & $6.63 \pm 0.90$ & 0.048 \\
\hline $\begin{array}{l}\text { reference } \\
\text { controls }\end{array}$ & 22 & $3.74 \pm 0.70$ & & $6.20 \pm 0.89$ & \\
\hline $\begin{array}{l}\text { Total } \\
\text { reference } \\
\text { controls }\end{array}$ & 280 & $4.40 \pm 0.72$ & $3.46 \mathrm{E}-8$ & $6.68 \pm 0.90$ & $2.80 \mathrm{E}-$ \\
\hline
\end{tabular}


medRxiv preprint doi: https://doi.org/10.1101/2021.05.25.21257799; this version posted May 27, 2021. The copyright holder for this preprint (which was not certified by peer review) is the author/funder, who has granted medRxiv a license to display the preprint in perpetuity.

All rights reserved. No reuse allowed without permission.

Table 3 Correlation of elevated LIGHT levels with organ failures in bacterial sepsis ${ }^{\#}$

\begin{tabular}{|l|l|l|l|l|l|}
\hline & & LIGHT & ARDS & AKI & Apache III \\
\hline LIGHT & $\mathbf{r}$ & - & $0.155^{*}$ & $0.162^{*}$ & $0.172^{*}$ \\
\hline & $\mathbf{p}$ value & - & 0.036 & 0.028 & 0.020 \\
\hline ARDS & $\mathbf{n}$ & - & 182 & 182 & 182 \\
\hline & $\mathbf{r}$ & $0.155^{*}$ & - & $0.157^{*}$ & $0.452^{* *}$ \\
\hline AKI & $\mathbf{p}$ value & 0.036 & - & 0.034 & 0.000 \\
\hline & $\mathbf{n}$ & 182 & - & 182 & 182 \\
\hline & $\mathbf{r}$ & $0.162^{*}$ & $0.157^{*}$ & - & $0.325^{* *}$ \\
\hline Apache III & $\mathbf{p}$ value & 0.028 & 0.034 & - & 0.000 \\
\hline & $\mathbf{n}$ & 182 & 182 & - & 182 \\
\hline & $\mathbf{r}$ & $0.172^{*}$ & $0.452^{* *}$ & $0.325^{* *}$ & - \\
\hline & $\mathbf{p}$ value & 0.020 & 0.000 & 0.000 & - \\
\hline & $\mathbf{n}$ & 182 & 182 & 182 & - \\
\hline
\end{tabular}

${ }^{\#}$ Controlled for age.

Table 4 Correlation of quantitative Ln(IL-18) levels with organ failures ${ }^{\#}$

\begin{tabular}{|l|l|l|l|l|l|l|}
\hline IL-18 & All cases & & \multicolumn{2}{l|}{ Bacterial sepsis } & \multicolumn{2}{l|}{ Viral sepsis } \\
\hline & r & p value & r & p value & r & p value \\
\hline ARDS & $0.121^{*}$ & 0.045 & 0.103 & 0.165 & 0.167 & 0.117 \\
\hline AHRF & $0.145^{*}$ & 0.017 & 0.101 & 0.175 & $0.251^{*}$ & 0.018 \\
\hline AKI & $0.187^{* *}$ & 0.002 & $0.151^{*}$ & 0.041 & $0.257^{*}$ & 0.015 \\
\hline Apache III & $0.301^{* *}$ & 0.000 & $0.278^{* *}$ & $1.40 \mathrm{E}-04$ & $0.340^{* *}$ & 0.001 \\
\hline LOS & 0.034 & 0.577 & 0.064 & 0.392 & -0.035 & 0.743 \\
\hline Mortality & $0.288^{* *}$ & 0.000 & $0.254^{* *}$ & 0.001 & $0.350^{* *}$ & 0.001 \\
\hline
\end{tabular}

${ }^{\#}$ Controlled for race. 
Table 5 Correlation of elevated LIGHT and Ln(IL-18) with biomarkers of organ failures

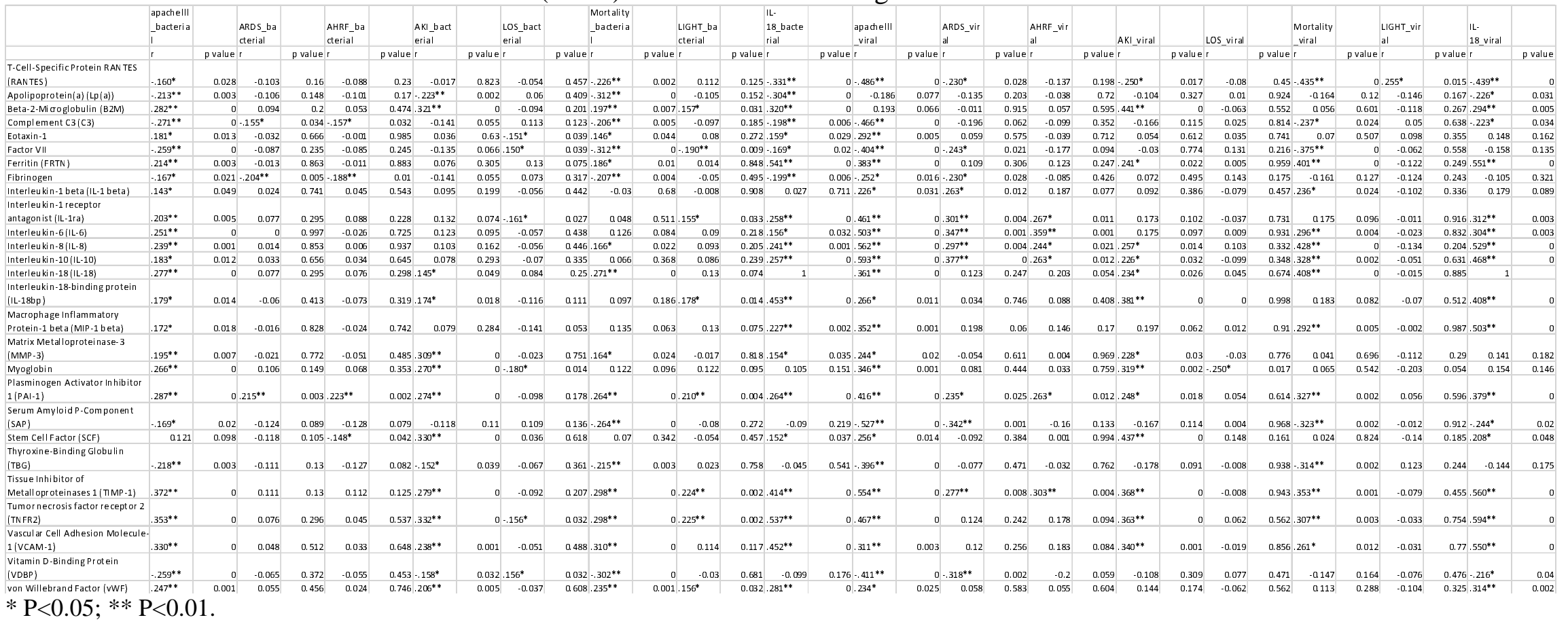




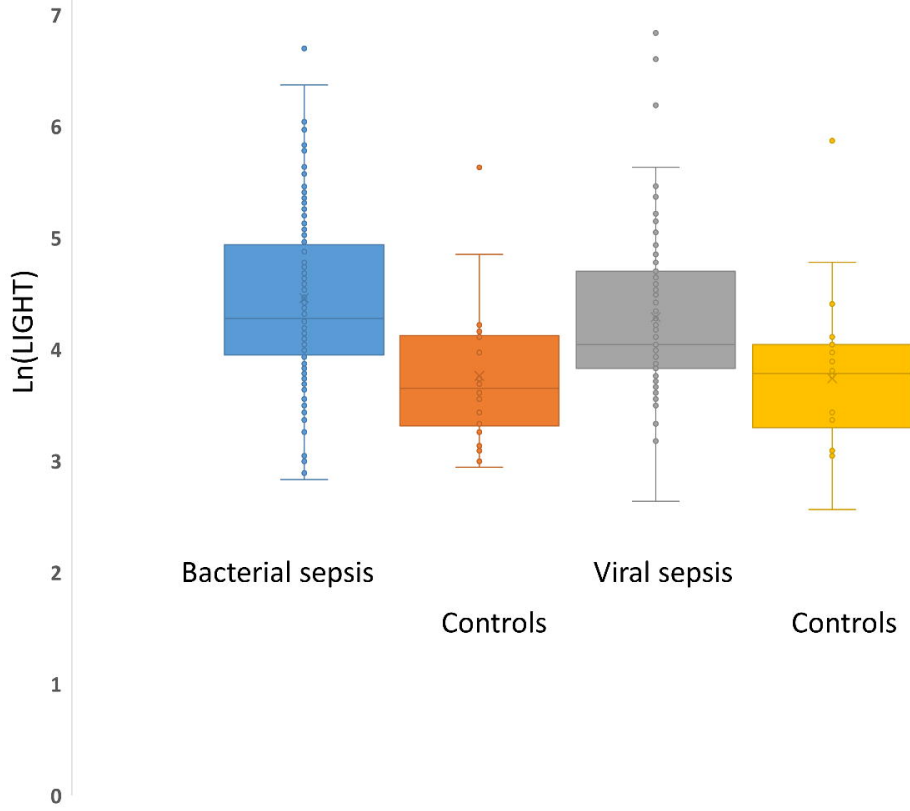

